\title{
History of the International Society for Research in Human Milk and Lactation
}

\author{
Armond S. Goldman \\ University of Texas Medical Branch, Galveston, TX, USA
}

\section{Keywords}

Human milk · Lactation - International Society for Research in Human Milk and Lactation

\begin{abstract}
The goal of this report is to recount the history of the International Society for Research in Human Milk and Lactation (ISRHML) and how its members contributed to the science of human milk (HM) and lactation (LT). The ISRHML was formed in 1988 by a group of young scientists who were intrigued with the mysteries of HM and LT and the effects of HM upon recipient human infants. The inception of the ISRHML by those scientists with many different types of interests and expertise led over the next 3 decades to a wealth of new information concerning the biology of the mammary gland and the exceptionally complex composition of HM. Those findings helped to explain why HM is by far the superior nutrition for human infants.

(C) 2021 S. Karger AG, Basel
\end{abstract}

\section{The Beginnings}

Breastfeeding was accepted as the best nutrition for human infants in the 19th century. However, as the industrial revolution progressed, the notion that man could improve upon nature became widespread [1]. That idea led to the development of processed bovine milk for feeding human infants. The abrupt upturn toward artificial feedings coincided with an upsurge of women entering the workforce [2]. Infant feeding thus became a major focus of the medical profession. Consequently, the control over the choice of infant feeding shifted from mothers to physicians.

Research in the early 20 th century regarding mammalian milk dealt primarily with major nutrients in cow milk. Most nutritionists and physicians believed that cow milk used for infant feeding and human milk (HM) were equivalent. There were, however, some disquieting notes. Quantities of caseins, beta-lactoglobulin, and saturated fats were higher in cow milk, whereas concentrations of carbohydrates and whey proteins were greater in HM. Moreover, certain epidemiological studies indicated that breastfed infants were less prone to certain illnesses. By the mid-20th century, many new research technologies were being developed. Thus, the time was ripe for a new look at the components of HM, how they were produced, and how they affected human infants.

As the 1970s dawned, a group of scientists with quite different types of expertise became interested in the largely neglected field of research into HM and lactation (LT). They were interesting, in that they had not trained with mentors who were interested in the field. In different ways, each became attracted to this area of science although funding for studies from resources was hard to 
obtain because of the lack of enthusiasm for this area of science among study sections of the National Institutes of Health of the USA or their counterparts in other countries.

Two other features were their appreciations of many scientific disciplines and their abilities to work with others in the nascent field. In the latter part of the 1970s, the interests of those scientists in the USA began to coalesce. The upshot was an initiative generated by Thorsten A. Fjellstedt, an administrative scientist at the National Institute of Child Health and Human Development. Fjellstedt was a visionary in many ways. His original training was in microbiology, but his bent was to reach out to many aspects of child health and aid in the development of outstanding science that would benefit infants and children. Fjellstedt recognized through his review of research grants that there was a growing interest in HM and LT. But the problem was how to channel support toward scientists who might conduct excellent studies in that field. Fjellstedt convinced his coworkers to encourage research proposals concerning HM and LT. The call for these proposals consolidated the interest in the field and attracted graduate students and postdoctoral fellows to join the research.

\section{Pioneers of the Society}

As research in HM began to increase, it was recognized that a meeting of these pioneers in the field was needed. Fjellstedt played a pivotal role in organizing the agenda and selecting participants for such a conference. The 1st conference held in Elk Ridge, Maryland, in 1982 (Table 1) examined methodologies in HM banking. At that meeting, it was recognized that many aspects of methods used to analyze HM required further study, and new methods were needed to address many key issues in the field.

A committee on methods chaired by Robert G. Jensen from the University of Connecticut was formed. The other members included Stephanie Atkinson from McMaster University in Canada, Cutberto Garza from Baylor College of Medicine, Bo Lönnerdal from the University of California at Davis, Margaret C. Neville from the University of Colorado, and Mary Francis Picciano from the University of Illinois. Afterward, Margit Hamosh from Georgetown University and Armond S. Goldman from the University of Texas Medical Branch in Galveston were added to that group.

Plans were laid for a 2nd conference held under the auspices of the National Institute of Child Health and $\mathrm{Hu}$ man Development focused upon laboratory research methodologies. Robert G. Jensen was the principal orga- nizer. Margaret C. Neville also played a major role in organizing the scientific program. An isolated, pastoral site in Winter Park, Colorado, was chosen for the site. About 50 scientists, many of whom became the core of a new research organization in the field of HM and LT, gathered for the event in August 1984 (Table 1).

It became clear at that conference that methodologies originally designed to measure the components of other biological systems were not necessarily ideal for investigating HM and LT. The presentations from the meeting were published in 1985 [3]. The publication heightened the interest in HM and LT.

The workshop atmosphere of the conference engendered a spirit of intellectual challenge and camaraderie that paved the way for a succession of research conferences devoted to HM and LT. Also, it appeared that a critical mass of investigators could be mobilized to warrant the creation of a new research society devoted to HM and LT. In fact, many of the attendants at that conference played important roles in the development of that research organization.

\section{Momentum Occurs}

A steering committee was created that recommended that the next conference be devoted to the effect of environmental and maternal factors upon human LT. Margit Hamosh was asked to form the conference. She requested Armond S. Goldman to help organize it. Salvador Villalpando and Samuel-Flores Huerta from the Unidad de Investigacion Biomedica in Mexico City graciously arranged for the meeting to be held in the picturesque, Spanish Colonial setting of Oaxaca, Mexico, where the ancient Mitex and Zapotec civilizations had been.

The conference was held in January 1986 (Table 1). As with the Winter Park Conference, there were vigorous presentations and discussions. The main areas of interest were the ethnic cultural determinants of LT, LT performance, effects of nutrition upon human LT, drugs and toxins in HM, and host defense factors in HM [4]. The conference also attracted many colleagues from Hispanic America and some from Europe. As with the preceding conference, the publication of the proceedings attracted great interest and encouraged the creation of an international society devoted to research in HM and LT.

Armond S. Goldman was asked to organize the 3rd conference. He in turn asked Stephanie Atkinson from McMaster University in Canada and Lars A. Hanson from Göteborg, Sweden, to help design a conference that focused on the effects of HM upon the recipient infant. A European site for the conference was chosen to attract
Ann Nutr Metab 2021;77:83-89 DOI: $10.1159 / 000515297$
Goldman 
Table 1. ISRHML conferences

\begin{tabular}{|c|c|c|c|}
\hline Year & Organizers & Topics and publications & Locations \\
\hline 1982 & Thorstein Fjellstedt & Human Milk Banking Methods & Elk Ridge, Maryland \\
\hline 1986 & Margit Hamosh and Armond S. Goldman & $\begin{array}{l}\text { 2nd International Conference. Human Lactation: Maternal and } \\
\text { Environmental Factors. Plenum Press, NY, } 1986\end{array}$ & Oaxaca, Mexico \\
\hline 1988 & $\begin{array}{l}\text { Stephanie Atkinson, Lars Å. Hanson, and } \\
\text { R. K. Chandra }\end{array}$ & $\begin{array}{l}\text { 4th International Conference. Breastfeeding. Nutrition, Infection } \\
\text { and Infant Growth in Developed and Emerging Countries. Arts } \\
\text { Biomedical Publishers and Distributors, St John's, Newfoundland, } \\
\text { Canada } 1990\end{array}$ & San Jose, Costa Rica \\
\hline 1990 & Mary Frances Picciano and Bo Lönnerdal & $\begin{array}{l}\text { 5th International Conference. Mechanisms Regulating Lactation } \\
\text { and Infant Nutrient Utilization. Wiley-Liss, Inc., New York, } 1992\end{array}$ & Asilomar, California \\
\hline 1995 & $\begin{array}{l}\text { Cutberto Garza, Kathy M. Rasmussen, and } \\
\text { Sal Villapando }\end{array}$ & 7th International Conference ISRHML & Tlaxcala, Mexico \\
\hline 1997 & David Newburg & $\begin{array}{l}\text { 8th International Conference. Bioactive Components of Human } \\
\text { Milk. Adv Exp Med and Biol 2001; } 501\end{array}$ & $\begin{array}{l}\text { Plymouth, } \\
\text { Massachusetts }\end{array}$ \\
\hline 1999 & $\begin{array}{l}\text { Berthold V. Koletzko, Olle Hernell, and } \\
\text { Kim F. Michaelsen }\end{array}$ & $\begin{array}{l}\text { 9th International Conference. Short \& Long-Term Effects of } \\
\text { Breastfeedng on Child Health. Adv Exp Med Biol 2000; } 478\end{array}$ & Irsee, Germany \\
\hline 2000 & $\begin{array}{l}\text { Margarette Davis, Charles Isaacs, Lars Å. } \\
\text { Hansen, and Anne Wright }\end{array}$ & 10th International Conference L. Adv Exp Med and Biol 2002; 503 & Tucson, Arizona \\
\hline 2002 & $\begin{array}{l}\text { Larry Pickering, Ardythe Morrow, Richard } \\
\text { Schanler, and Guillermo Ruiz-Palacios }\end{array}$ & $\begin{array}{l}\text { 11th International Conference: Protecting Infants Through Human } \\
\text { Milk. Adv Exp Med and Biol 2004; 554:522 }\end{array}$ & Mexico City, Mexico \\
\hline 2010 & $\begin{array}{l}\text { Rafael Perez-Escamilla, Mary Penny, } \\
\text { Theresa Ochoa, and Rossina Pareja }\end{array}$ & $\begin{array}{l}\text { 15th International Conference of ISRHML. Abstracts. J Human } \\
\text { Lactation 2010; 26:419-445 }\end{array}$ & Lima, Peru \\
\hline 2012 & $\begin{array}{l}\text { Paula Meier, Riccardo Davanzo, Peter } \\
\text { Hartmann, Shelley McGuire, Mark McGuire, } \\
\text { and Theresa Ochoa }\end{array}$ & $\begin{array}{l}\text { 16th International Conference: Abstracts: Breast-Feeding: } \\
\text { Breastfeeding and the Use of Human Milk: Science and Practice. } \\
\text { Breastfeeding Medicine 2012; 7:556-577 }\end{array}$ & Trieste, Italy \\
\hline 2014 & Rafael Perez-Escamilla and Carol Wagner & $\begin{array}{l}\text { 17th ISRHML Conference: Abstracts. J Human Lactation 2015; } \\
\text { 31:530-551 }\end{array}$ & $\begin{array}{l}\text { Kiawah Island, } \\
\text { South Carolina }\end{array}$ \\
\hline 2016 & $\begin{array}{l}\text { Lars Bode, Evette van Niekerk, and } \\
\text { Lisanne du Plessis }\end{array}$ & $\begin{array}{l}\text { 18th ISRHML Conference Abstracts: Breastfeeding Medicine 2016; } \\
\text { 11: A3-79 }\end{array}$ & $\begin{array}{l}\text { Stellenbosch, } \\
\text { South Africa }\end{array}$ \\
\hline 2018 & Sharon Donovan and Katsumi Mizuno & $\begin{array}{l}\text { 19th ISRHML Conference. Abstracts. Breastfeeding Medicine 2018; } \\
\text { 13: A1-68 }\end{array}$ & Kanagawa, Japan \\
\hline
\end{tabular}

ISRHML, International Society for Research in Human Milk and Lactation. 
Europeans into the new research society and to encourage collaboration between groups from both sides of the Atlantic. Fortunately, Dr. Gerd Harzer, a German scientist who was studying certain components in HM, learned about the idea and volunteered to arrange for the meeting to be held in Konstanz, West Germany, in September 1986 (Table 1).

At the conference in Konstanz, over 60 scientists addressed the nutritional, epidemiological, metabolic, hormonal, immunological, and toxicological aspects of the issues. The site in Western Europe was ideal from many points of view. As with the Oaxaca conference, the cultural setting facilitated an exchange of ideas and permitted vigorous but friendly debate that became a hallmark of the soon to be formed research society. Questions pinpointed at that meeting still resonate. Will investigations of the physicochemical structures of components in HM lead to a discovery of new functions of the components? How do the components interact? What animal models are suitable to test the effects of HM upon the recipient human infant? How do the components interact with the mucosa of the recipient infant? Are there systemic effects of HM? If so, what bioactive factors in HM are responsible for those effects? The publication of the conference [5] generated more interest among members of the research community.

\section{Formation of the ISRHML}

Final plans were made to form the International Society for Research in Human Milk and Lactation (ISRHML). All participants in the first 3 conferences were invited to join the new society. Elections for officers were held. In 1988, Margit Hamosh became the 1st President (Table 2), Leif Hambreaus (Sweden), the 1st President-Elect, and Kathryn Dewey (University of California at Davis), the 1st Secretary/Treasurer. Members of the 1st Executive Committee were Lindsey H. Allen (University of California, Davis), Stephanie Atkinson, Armond S. Goldman, Lars A. Hansen, Ruth Lawrence (University of Rochester), Bo Lönnerdal, Audrey Naylor (University of California, San Diego), Mary Frances Picciano, Guy Putet (Hopital Edouardo Herroit in Lyons, France), and Richard J. Schanler (Baylor College of Medicine, Houston).

The laws and bylaws of the society were formulated principally by Margaret C. Neville with some assistance from Margit Hamosh and Armond S. Goldman. The document provided the framework for the subsequent operation and development of the society. The goals were to formulate excellent science in the field of HM and LT, bring together investigators in all aspects of the field, and
Table 2. Presidents of the ISRHML

\begin{tabular}{ll}
\hline Years served & Presidents \\
\hline $1988-1989$ & Margit Hamosh \\
$1990-1991$ & Leif Hambreaus \\
$1992-1993$ & Cutberto Garza \\
$1994-1995$ & Mary Frances Picciano \\
$1996-1997$ & Armond S. Goldman \\
$1998-1999$ & Salvador Villalpando \\
$2000-2001$ & Richard J. Schanler \\
$2002-2003$ & Kathleen M. Rasmussen \\
$2004-2005$ & Kim F. Michaelsen \\
$2006-2007$ & Kathryn G. Dewey \\
$2008-2009$ & Peter E. Hartmann \\
$2010-2011$ & Ardythe L. Morrow \\
$2012-2013$ & Paula P. Meier \\
$2014-2015$ & Rafael Perez-Escamilla \\
$2016-2017$ & Lars Bode \\
$2018-2019$ & Sharon M. Donovan \\
$2020-2021$ & Berthold V. Koletzko \\
\hline
\end{tabular}

ISRHML, International Society for Research in Human Milk and Lactation.

aid in the development of young researchers to carry the endeavors into the future. Indeed, the intertwining of renewal and continuity ran through the document and through the minds of those who founded the society. It was understood at the beginning that the society would be composed of individuals who were devoted to research into the subject and were poised to make future contributions.

\section{Steady Progress}

Over the next decade, international conferences were held in Costa Rica (1988), Asilomar, California (1990), Stockholm, Sweden (1992), Tlaxcala, Mexico (1995), Plymouth, Massachusetts (1997), and Irsee, Germany (1999) (Table 1). In addition, annual symposia were held in conjunction with the Experimental Biology meetings in the USA. The society also helped to spawn the Milk Club, a group of academic pediatricians who met annually at the conjoined meetings of the American Pediatric Society and the Society for Pediatric Research.

The society was well served by a succession of excellent officers and members of the Executive Committee. During the first 12 years of the society, the Presidents following Margit Hamosh were Leif Hambraeus (Uppsala University in Sweden), Cutberto Garza (Cornell University), Mary Frances Picciano (Pennsylvania State University), Armond S. Goldman, Salvador Villalpando, and Richard
86

Ann Nutr Metab 2021;77:83-89 DOI: $10.1159 / 000515297$
Goldman 
Table 3. Recipients of the Macy-György and Ehrlich-Koldovsky Awards concerning HM, LT, and BF

\begin{tabular}{ll}
\hline Macy-György awardees & Ehrlich-Koldovsky awardees \\
\hline 1994: Robert G. Jensen: HM nutrition & 1995: Sharon Donovan: HM components \\
1996: Stuart Patton: HM fat globules & 1997: Ardythe Morrow: Support of BF \\
1998: Margit Hamosh: HM enzymes & 1999: Rafael Perez-Escamilla: Epidemiology \& BF \\
2000: Armond S. Goldman: HM immunology & 2000: Bohuslav Dvorak: HM growth factors; Cheryl Lovelady: LT \\
2002: Bo Lönnerdal: HM components & 2002: Johanna Hawkes: Cytokines \& HM cells \\
2004: Lars Å. Hansen: HM immunology & 2004: Michelle McGuire: Prebiotics, probiotics HM \\
2006: Peter E. Hartmann: HM bioactive agents & 2006: Shannon Kelleher: HM zinc \\
2008: W. Allan Walker: HM immunology & 2008: Mark Cregan: HM stem cells; Donna Geddes: LT \\
2010: Mary Frances Picciano: HM agents & 2010: Stefano Bembich: BF \& brain activation \\
2012: Kathryn G. Dewey: HM nutrition & 2012: Lars Bode: HM oligosaccharides \\
2014: Margaret C. Neville: Human lactation & 2014: Foteini Kakulas: HM epithelial cells \\
2016: Kathleen M. Rasmussen: HM nutrition & 2016: Katie Hinde: Evolution \& BF \\
2018: Ann Prentice: HM composition & 2018: Meghan Azad: Maternal nutrition \& HM \\
\hline
\end{tabular}

HM, human milk; LT, lactation, BF, breast feeding.

J. Schanler (Table 2). The Secretary/Treasurers following Kathryn G. Dewey were Nancy Butte (Baylor College of Medicine, Houston), Armond S. Goldman, Ruth Lawrence, and Frank Greer (University of Wisconsin, Madison). These officers along with the members of the Executive Committee provided the leadership for the international society and in doing so ensured that the members of the society would be able to participate and have opportunities to become leaders in their own right.

The members of the society recognized in 1994 that it was essential to establish an ethical code for the operation of the international society. The ethical code was prepared principally by Jean-Pierre Habicht (Cornell University) and was accepted by the society after a thorough review. The guidelines were established to design the meetings of the society and deal with donors and their donations.

The society decided in 1994 to create an award to recognize senior scientists who had made outstanding contributions to the field of HM and LT. The award was named in honor of Icie Gertrude Macy Hoobler from the University of California, Berkeley, for her pioneering studies in LT performance and Paul Györgi from Philadelphia General Hospital for his research concerning host resistance factors in HM. The 1st Macy-Györgi Award for Research in Human Milk and Lactation was given to Robert G. Jensen from the University of Connecticut, a founder of the society, for his many discoveries concerning lipids in HM (Table 3). The 2nd awardee, Dr. Stuart Patton from the University of San Diego, was recognized for his many salient studies including the structure and compo- nents of milk fat globules. The 3rd awardee was Dr. Margit Hamosh from Georgetown. Hamosh, one of the founders and the 1st President of the society, was recognized for her excellent research into lipids, enzymes, and immune factors in HM and the way that the recipient infant deals with and is affected by those agents. The award was bestowed upon Armond S. Goldman in 2000 for his investigations of the immune system in HM, Bo Lönnerdal in 2002 for his studies in the nutrients in HM, Lars $\AA$. Hansen in 2004 for his pioneering studies of the immune components of HM, Peter Hartmann in 2006 for his investigations of the production of $\mathrm{HM}$ and its components, W. Allan Walker in 2008 for his findings concerning the immune protection by HM, Mary Frances Picciano in 2010 for her studies of maternal nutritional requirements, Kathryn Dewey in 2012 for her investigations of the effects of nutrient supplementations upon HM, Margaret C. Neville in 2014 for her investigations of the molecular mechanisms responsible for the functions of the mammary gland, Kathleen M. Rasmussen in 2016 for demonstrating that improving maternal nutrition enhances the volume and composition of HM, and Ann Prentice in 2018 for her investigations of nutrient requirements in lactating women and nutrients in HM (Table 3).

The society from its inception encouraged the development of young investigators. The Early Career Award was established in 1995. In 1999, the award was named after Paul Ehrlich, who 1st discovered that the mammary gland was an immunological organ, and Otakar Koldovsky from the University of Arizona, who conducted pioneer- 
ing studies on hormones and growth factors in HM and their fate in and effects on the recipient infant. The recipients of the Ehrlich-Koldovsky Award were Sharon M. Donovan (1995), Ardythe L. Morrow (1997), Rafael Perez-Escamilia (1999), Bohuslav Dvorak and Cheryl Lovelady (2000), Johanna Hawkes and Michelle (Shelley) McGuire (2002), Shannon Kelleher (2006), Mark Cregan and Donna Geddes (2008), Stefano Bembich (2010), Lars Bode (2012), Foteini Kakulas (2014), Katie Hinde (2016), and Meghan Azad (2018) (Table 3).

Since the society was established in 1988, the membership grew steadily and involved scientists from many different disciplines including anthropology, biochemistry, epidemiology, genetics, human evolution, immunology, LT biology, maternal and child health, metabolism, microbiology, molecular biology, nutrition, physiology, toxicology, and related areas. The group remained highly interactive. New scientists were attracted to the field and became dedicated to the promulgation of excellent science in HM and LT.

Biannual meetings of the ISRHML continued to be held (Table 1). They were in San Jose, Costa Rica, in 1988 (organizers: Stephanie Atkinson, Lars A. Hansen, and Ranjit K. Chandra); Asilomar, California, in 1990 (organizers: Mary Frances Picciano and Bo Lönnerdal); Stockholm, Sweden/Helsinki, Finland, in 1992 (organizers: Leif Hambraeus, Bo Lönnerdal, Janet King, and Lindsey Allen); Tlaxcala, Mexico, in 1995 (organizers: Cutberto Garza, Kathy Rasmussen, and Salvador Villalpando); Plymouth, Massachusetts, in 1997 (organizer: David Newburg); Irsee, Germany, in 1999 (organizers: Berthold Koletzko, Olle Hernell, and Kim Michaelsen); Tucson, Arizona, in 2000 (organizers: Margarette Davis, Charles Isaacs, Lars $\AA$. Hansen, and Anne Wright); Mexico City, Mexico, in 2002 (organizers: Larry Pickering, Ardythe Morrow, Richard Schanler, and Guillermo Ruiz-Palacios); Queens College, UK, in 2004 (organizers: Gail Goldberg, Andrew Prentice, Ann Prentice, Suzanne Filteau, and Kirsten Somondon); Niagara-on-the-Lake, Canada, in 2006 (organizers: Olle Hernell, Bo Lönnerdal, Stephanie Atkinson, Debbie O'Connor, Daniel Sellen, and Ruth Lawrence); Perth, Australia, in 2008 (organizers: Ardythe Morrow, Peter Hartmann, Mark Cregan, and Donna Geddes); Lima, Peru, in 2010 (organizers: Rafael Perez-Escamillia, Mary Penny, Theresa Ochoa, and Rossina Pareja); Trieste, Italy, in 2012 (organizers: Paula Meier, Riccardo Davanzo, Peter Hartmann, Shelley McGuire, Mark McGuire, and Theresa Ochoa); Kiawah, South Carolina, in 2014 (organizers: Rafael Perez-Escamilla, and Carol Wagner); Stellenbosch, South Africa, in
2016 (organizers: Lars Bode, Evette van Niekerk, and Lisanne du Plessis); and Kanagawa, Japan, in 2018 (organizers: Sharon Donovan and Katsumi Mizuno). The 2021 conference organized by Berthold Koletzko and Magnus Domellöf will be held in Stockholm, Sweden.

A Trainee Interest Group and a Trainee Expansion Program were urged by Sara Moukarzel from the University of British Columbia in Canada when she received an ISRHML Trainee Travel Award for the Experimental Biology meeting in San Diego in 2014. Consequently, the laws and bylaws of the ISRHML were changed to include a Trainee Interest Group.

The idea for a Trainee Expansion Program was developed by the ISRHML President-Elect Lars Bode and by Janet Prince, who then was the only employee of the newly formed Family Larsson-Rosenquist Foundation. The concept was further developed when Dr. Katharina Lichtner became the Managing Director of the Family LarssonRosenquist Foundation. The program was launched at the ISRHML conference in South Africa in 2016 (Table 1). The Family Larsson-Rosenquist Foundation committed the first 1 million dollars to support the Trainee Expansion Program ( USD 200,000 per year for 5 years).

The Family Larsson-Rosenquist Foundation funds for the Trainee Expansion Program and expenses related to it (providing awards of USD 10,000 and USD 100,000 to different universities and institutions around the world) exceeded the roles of the secretary/treasurer of the ISRHML. Consequently, the ISRHML President Lars Bode initiated the move from a member volunteer management to a professional association management. That was officially instituted in 2018.

A salient outcome of the creation of the ISRHML was the development of more collaborations between scientists who were investigating HM and LT. In addition, the new knowledge in the field significantly influenced pediatricians, obstetricians, other physicians, nurses, other health-care professionals, and the general public that HM was the ideal nutrition for human infants. Consequently, the frequency of breastfeeding (BF) in industrialized countries gradually rose from a nadir of 5-10 percent in the 1970 s to about 80 percent $[6,7]$. The rates of exclusive BF correspondingly increased particularly in mothers with high educational levels in European countries such as Denmark, the Netherlands, and Germany [8].

Many health benefits occurred because of the increased $\mathrm{BF}$. Some examples are as follows. The incidence and intensity of many infectious diseases in human infants fell [9]. The incidence of necrotizing enterocolitis was lessened in preterm infants fed HM [10]. Breastfed children 
were protected against certain inflammatory diseases long after weaning [9]. Many positive psychological effects of BF on the mother and the child were discovered [11]. Furthermore, BF was found to lessen the risks of obesity in young children [12].

As the ISRHML entered the 21st century, there was a spirit of optimism among its members because of many new opportunities to explore the mysteries of the human mammary gland, HM, and the interrelationships between the secretions of the mammary gland and the biology of the recipient infant. Therefore, researchers in the field of $\mathrm{HM}$ and LT look forward to further accomplishments in research in HM and LT. More will be forthcoming. Thus, in a few decades, the history of the ISRHML will have to be recounted again.

\section{Conflict of Interest Statement}

The author has no conflict of interest to declare.

\section{Funding Sources}

The author has no funding sources to declare.

\section{References}

1 Goldman AS. Breastfeeding: lessons from the past century. Pediatr Clin North Am. 2001; 48(2):xxiii-v

2 Wolf JH. Low breastfeeding rates and public health in the United States. Am J Public Health. 2003;93(12):2000-10.

3 Jensen RG, Neville MC, editors. Human lactation: milk components and methodologies. New York: Plenum Press; 1985.

4 Hamosh M, Goldman AS, editors. Human lactation 2. Maternal and environmental factors. New York and London: Plenum Press; 1986.

5 Goldman AS, Atkinson SA, Hanson LA, editors. Human lactation 3: the effects of human milk on the recipient infant. New York and London: Plenum Press; 1987.
6 Eckhardt KW, Hendershot GE. Analysis of the reversal in breast feeding trends in the early 1970s. Public Health Rep. Jul-Aug 1984; 99(4):410-5.

7 Centers for Disease Control and Prevention. Key breastfeeding indicators of infants born in 2017, National Immunization Survey (NIS). 2018-2019. Accessed from 2020 Dec 17.

8 Sarki M, Parleska A, Robertson A. Comparison of national cross-sectional breast-feeding surveys by education in Europe (2006-2016). Public Health Nutr. 2019 Apr;22(5):848-61.
9 Goldman AS, Chheda S, Keeney SE, Schmalstieg FC. Immunology of human milk and host immunity. In: Polin RL, Abman S, Benitz WE, Rowitch DH, editors. Fetal and neonatal physiology. 5th ed. Philadelphia, Penn: Elsevier; 2017.

10 Lucas A, Cole TJ. Breast milk and neonatal necrotising enterocolitis. Lancet. 1990 Dec 22-29;336(8730):1519-23.

11 Krol KM, Grossmann T. Psychological effects of breastfeeding on children and mothers. Bundesgesundheitsblatt Gesundheitsforschung Gesundheitsschutz. 2018 Aug;61(8): 977-85.

12 von Kries R, Koletzko B, Sauerwald T, von Mutius E, Barnert D, Grunert V, et al. Breast feeding and obesity: cross sectional study. BMJ. 1999 Jul 17;319(7203):147-50. 